Artikel Riset

DOI : $10.33751 /$ jf.v8i2.1570
Fitofarmaka Jurnal Ilmiah Farmasi

Vol.8, No.2, Desember 2018

p-ISSN : 2087-9164 e-ISSN : 2622-755X

\title{
GEOGRAPHYCAL EFFECT ON THE CYTOTOXIC ACTIVITY OF Annona muricata L. LEAVES ETHANOL EXTRACT AGAINST MCF-7 CANCER CELL
}

\author{
Usep Suhendar \\ Department of Pharmacy, Faculty of Mathematic and Natural Sciences, \\ Universitas Pakuan \\ Email: suhendar_usep@yahoo.com
}

Received : 28 August 2018

Revised : 20 November 2018

Approved : 23 December 2018

\begin{abstract}
Many studies have shown the anti-cancer activities of the chemical compounds extracted from the leaves of Annona muricata or soursop plant. Cianjur and Sukabumi are quite large soursop producing area in Indonesia. This study was carried out to determine the difference of cytotoxic activity of soursop leaves ethanolic extract which were harvested from three different areas of Cianjur (I, II, III) and Sukabumi (I, II, III). The Soursop leaves were macerated with $70 \%$ ethanol using microwave assisted extraction (MAE) method. The extract was tested in vitro on breast cancer cell line MCF7 and its constituent was identified using GC-MS apparatus. The results showed that the highest cytotoxic activity with $\mathrm{IC}_{50}$ values of $9.12 \mu \mathrm{g} \mathrm{ml}^{-1}$ was determined on the extract of soursop leaves harvested from Cianjur III area. Qualitative identification of chemical constituent shows that the soursop leaves contain alkaloid, flavonoid, triterpenoid, tannin and saponin compounds. No steroid compound was detected in the extract. It can be concluded that the geographical regions affected the biochemical properties of soursop leaves.
\end{abstract}

Keyword : Anticancer, breast cancer, cytotoxic, MCF-7, soursop leaf extract

\section{AKTIVITAS SITOTOKSIK EKSTRAK ETANOL DAUN SIRSAK (Annona muricata L.) BERDASARKAN EFEK GEOGRAFIS TERHADAP SEL KANKER MCF-7}

\begin{abstract}
ABSTRAK
Berbagai penelitian menunjukkan bahwa ekstrak daun sirsak (Annona muricate) mengadung senyawa-senyawa yang memiliki aktifitas anti kanker. Sukabumi dan Cianjur merupakan daerah-daerah penghasil sirsak yang cukup besar di Indonesia. Penelitian ini bertujuan untuk melihat perbedaan aktifitas sitotoksik ekstrak daun sirsak yang diperoleh dari tiga daerah berbeda di Cianjur (I, II, III) and Sukabumi (I, II, III). Daun sirsak dimaserasi menggunakan metode microwave assisted extraction (MAE) dengan pelarut alcohol $70 \%$. Senyawa-senyawa yang terkandung dalam ekstrak diidentifikasi menggunakan alat GC-MSEkstrak selanjutnya diujikan aktifitas sitotoksiknya terhadap sel kanker galur MCF-7. Hasil penelitian menunjukkan aktifitas sitotoksik terlihat pada sel kanker dengan perlakuan ekstrak daun sirsak dari daerah Cianjur III dengan nilai IC $_{50} \quad 9,12 \mu \mathrm{g} \mathrm{ml}^{-1}$ Identifikasi senyawa kimia secara kualitatif menunjukkan bahwa ekstrak daun sirsak mengandung senyawa-senyawa alkaloid, flavonoid, triterpenoid, tannin dan saponin, dan tidak mendeteksi adanya senyawa golongan steroid. Dari penelitian ini dapat disimpulkan bahwa letak geografis tempat tanam mempengaruhi kandungan senyawa kimia pada tanaman.
\end{abstract}

Kata Kunci : Antikanker, kanker payudara, sitotoksik, MCF-7, ekstrak daun sirsak 


\section{INTRODUCTION}

Breast cancer is the second leading cause of cancer death in women. The chance that a woman will die from breast cancer is about 1 in 38 (about 2.6\%). The brast cancer is more common found in developed countries and is more than 100 times more common in women than in men. Based on data from the World Health Organization in 2012 patients with cancer in Southeast Asia as much as 1.171 million people died and 1.728 million new findings of cancer (IARC 2012). Breast cancer is a cancer that occurs in the mammary gland, duct glands, and other breast supporting tissues (Purwatiningsih et al., 2008; Raymond 2007). Worldwide, breast cancer is the leading type of cancer in women, accounting for $25 \%$ of all cases. In 2012 it resulted in 1.68 million new cases and 522,000 deaths (Shah et al., 2013). Breast cancer is treated in several ways including surgery, chemotherapy, hormonal therapy and radiation therapy depend on the kind of breast cancer and how far it has spread.

Chemotherapy treatment of breast cancer can cause both temporary side effects that stop soon after treatment finishes and longer-term side effects. On going side effects, such as hot flushes fatigue and extreme tiredness (Bruton et al., 2005; Wamidh 2011). Doxorubicin is a chemotherapy drug used to treat many different types of cancer. It slows or stops the growth of cancer cells by blocking an enzyme called topo isomerase 2. Cancer cells need this enzyme to divide and grow. However, this anticancer drug also affects other organs like brain, kidney and liver (Bruton et al., 2005). Considering the negative effect of chemotherapy, the discovery of new anticancer agents with fewer side effects still need to be pursued particularly with the use of natural products as a platform for drug development.

Soursop (Anonna muricata L.)which belongs to Annonaceae family is a plant that grows in tropical areas. The chemical compounds extracted from the leaves of this plant exhibit pharmacological properties such as anti-cancer, antiinflammatory, anti-diabetic and free radical scavenging activity (Moghadamtousi et al., 2015). Many studies show that soursop leaves has a range biological activities such as wound healing, antimicrobial, induces apoptosis, antioxidant and cytotoxic activity on cancer cell without affecting a normal cells (Solomon-Wisdom et al., 2014; Artini et al., 2012; Moghadamtousi et al., 2014; Paarakh et al., 2009). Soursop has also been reported to have significant anti-cancer effects in a number of cancer cell lines both in vitro and in vivo including anti-proliferative effects of HL-60 cells and MCF-7 tumor growth (Dai et. al., 2011). Other study of Rodriguez et al. (2010) also stated that the soursop leaves can be used in the treatment of cancer case and prevent cancer growth.

In this study, the leaves of soursop fruit cultivated in Cianjur dan Sukabumi regions was prepared, extracted and furthermore tested on the breast cancer cell line MCF-7.

\section{MATERIAL AND METHOD Material}

Fresh soursop leaves collected from six different areas namely Sukasirna (Cianjur I), Sukasarana (Cianjur II), Ciherang (Cianjur III), Coral Pakpak (Sukabumi I), Coral Pakpak (Sukabumi II), and Sukasari (Sukabumi III). The leaves then were cleaned under running tap water in the oven at $50{ }^{\circ} \mathrm{C}$. The MCF7 cancer cells was obtained from the Laboratory of Microbiology and Immunology, Wildlife and Primate Study Center, Indonesia.

\section{Extraction of Sample}


Each dried leaves of samples were extracted with $70 \% \mathrm{v} / \mathrm{v}$ ethanol using microwave assisted extraction method (MAE). The MAE method has a number of advantages such as shorter extraction time, less solvent, higher extraction rate and lower cost. The extracts obtained were then filtered through a Whatman No. 1 filter paper. The collected filtrates were evaporated to dryness under vacuum at $40^{\circ} \mathrm{C}$ using a rotary evaporator. The samples were prepared according to the method of AOAC (1984), Hasan (2013) and Herman et al. (2013) with a minor modification. All chemical used were of analytical grade.

\section{Qualitative analysis of chemical components of the extract}

The qualitative analysis of chemical constituents was carried out to detect the presence of alkaloids, flavonoids, steroids, triterpenoids, tannins and saponins in the ethanol extract of soursop leaves. The qualitative analysis was performed according to Harbone (1987), Gajalakshmi et al.(2012) and Hasan (2013) methods. A total $100 \mathrm{mg}$ of dry extract were dissolved in $1 \mathrm{~mL}$ of 99\% ethanol. The $1 \mathrm{~mL}$ solution then injected into capillary column HP-5 (Agilent 19091J-433: 0:25 mm $\times 30 \mathrm{~mm} \times$ 0:25 $\mu \mathrm{m}$ containing 5\% diphenyl $95 \%$ dimethylpolysiloxane) of GC-MS. The flow rate used was $1.0 \mathrm{~mL} / \mathrm{min}$, the injection temperature was $300{ }^{\circ} \mathrm{C}$, the pressure was 10:47. The GC-MS was running using split mode with the $\mathrm{He}$ (Helium) was used as a mobile phase. MS parameter was used to detect compounds with masses 50-800. MS quad was set at temperature of 150$200^{\circ} \mathrm{C}$ and MS source at $250-300^{\circ} \mathrm{C}$. The chromatogram resulted was analyzed by comparing it to the available database.

\section{Determination of Total Phenolic Compound}

The $0.5 \mathrm{ml}$ of $10 \%$ extract solution was added with $5 \mathrm{ml}$ of Folin-Ciocalteu reagent and $4 \mathrm{ml}$ of $10 \% \mathrm{Na}_{2} \mathrm{CO}_{3} 1 \mathrm{M}$. The mixture solution was shaked using vortex then incubated for $15 \mathrm{~min}$ at room temperature. Phenolic compounds were measured at a wavelength of 765 $\mathrm{nm}$. The standard curve was made using a series of gallic acid solution $0,50,100$, 150, 200, 250 and $300 \mathrm{mgl}^{-1}$ in methanol:water $(1: 1 \mathrm{v} / \mathrm{v})$. The amount of total phenolic compounds for each extract were calculated using linear regression equation obtained from the absorbance values of each extract plotted on equation of gallic acid standard curve.

$y=a+b x$

(1)

$$
\begin{aligned}
& \text { Description: } \\
& \mathrm{y}: \text { the dependent variable } \\
& \mathrm{x}: \text { the independent variable } \\
& \mathrm{a}: \text { intercept } \\
& \mathrm{b}: \text { regression coefficient/slope }
\end{aligned}
$$

\section{MTT test against cancer cells MCF-7}

The MTT test is a colorimetric assay for assessing cell metabolic activity. The NAD(P)H-dependent cellular oxidoreductase enzymes under defined conditions could reflect the number of viable cells present. These enzymes are capable of reducing the tetrazolium dye MTT use 3-(4,5-dimethylthiazol-2-yl)2,5-diphenyltetrazolium bromide to its insoluble formazan, which has a purple color. MTT test on MCF-7 cancer cells was performed based on Lin et al., (1991) and Hasan et al., (2013) method. Soursop leaf extract was dissolved in DMSO (dimethyl sulfoxide) to prepare a $10 \%$ solution stock solution. The stock solution then diluted with RPMI-1640 medium (Roswell Park Memorial Institute) to obtain $1 \%$ solution. A series of solution in different concentration ranging from 250 , $100,50,10$, and $1 \mathrm{mg} \mathrm{ml}^{-1}$ were then prepare from the $1 \%$ stock solution. The 
$20 \mathrm{~mL}$ of solution was taken from each concentration then added to the microplate containing $100 \mathrm{~mL}$ sustainable cell cancer $\left(7.5 \times 10^{4}\right.$ cells ml ${ }^{-1)}$ and incubated for 24 hours at $37{ }^{\circ} \mathrm{C}$ in an incubator with $5 \%$ $\mathrm{CO}_{2}$. DMSO $(0.05 \%)$ was used as a negative control and doxorubicin $(0.5 \mathrm{mg}$ $\mathrm{ml}^{-1)}$ as positive control. The number of survived cells were measured using ELISA reader at a wavelength of 570 nm. Data obtained were converted into percentage $(\%)$ of living cell using equation below:

The percentage of Living Cells $(\%)=$

$=\frac{(\text { Treatment absorbance }- \text { media control absorbance })}{(\text { control cell absorbance }- \text { media control absorbance })} \times 100$

\section{RESULTS AND DISCUSSION Extracts}

The extraction of soursop dry leaves using MAE methods show that the highest yield of extract was obtained from the leaves collected from Cianjur III area and lowest yield was obtained from the soursop leaves collected from Sukabumi III area with total yield $13.48 \%$ and $8.68 \%$ respectively as shown in Table 1 . The differences of extract yield indicated the differences in content and variety of

Table 2. The Compounds Detected In Soursop Leaves Ethanol Extract

\begin{tabular}{|c|c|c|c|c|c|c|c|c|}
\hline \multirow{3}{*}{ Location } & \multicolumn{8}{|c|}{ Type test } \\
\hline & \multicolumn{3}{|c|}{ Alkaloids } & \multirow{2}{*}{ Triterpenoid } & \multirow{2}{*}{ Steroid } & \multirow{2}{*}{ Flavonoid } & \multirow{2}{*}{ Tanin } & \multirow{2}{*}{ Saponin } \\
\hline & Dragendorf & Meyer & Wegner & & & & & \\
\hline Cianjur I & +++ & ++ & ++ & +++ & - & + & ++ & ++ \\
\hline Cianjur II & +++ & ++ & +++ & +++ & - & +++ & + & ++ \\
\hline Cianjur III & +++ & ++ & +++ & ++ & - & +++ & +++ & ++ \\
\hline Sukabumi I & +++ & ++ & +++ & + & - & + & +++ & +++ \\
\hline Sukabumi II & +++ & +++ & +++ & +++ & - & ++ & + & ++ \\
\hline $\begin{array}{l}\text { Sukabumi } \\
\text { III }\end{array}$ & +++ & +++ & +++ & +++ & - & +++ & ++ & +++ \\
\hline
\end{tabular}

note : - : not detected,$+:$ less detected, $++:$ well detected, $+++:$ very well detected chemical compounds contained in each sample. The data confirmed that the geographic area influences the chemical characteristics of plant compounds.

Table 1. The Yield of Soursop Leaves Extracted With 70\% Ethanol Using MAE Method

\begin{tabular}{lccc}
\hline \multirow{2}{*}{ Location } & \multicolumn{3}{c}{ Yield (\% w/w) } \\
\cline { 2 - 4 } & Site I & Site II & Site III \\
\hline Cianjur & 9.32 & 10.00 & 13.48 \\
Sukabumi & 10.92 & 11.40 & 8.68 \\
\hline
\end{tabular}

\section{Qualitative Test of Chemical Compounds In Soursop Extract}

The results of qualitative test detected the presence of alkaloids, flavonoids, triterpenoids, saponins and tannins compounds in soursop ethanol extracts (Table 2). No trace of steroid compounds found in the extract. The absence of steroid compounds in line with the previous research by Artini (2012) which showed similar results but different from the results of Solomon et al. study (1999) that found the streoid compounds in the extract of soursop leaves. This difference is probably related to differences in the method and solvent used in the study. 
Identification of Chemical Compounds In Soursop Extract

The identification of chemical compounds in soursop extract was performed using GC-MS apparatus. The chemical compounds found in the extracts was determined by comparing the similarity of pattern resulted from GC-MS reading with the pattern of available database. From the GC-MS reading, it was identified that ethanol extract of soursop leaves contains many identified compounds at different concentration as shown in Tabel 3. The compounds contained in soursop extract commonly belong to alkaloids, flavonoids, and phenols group. According to many literatures, these groups of compound have an activity as antidiabets, antioxidant and anticancer.

The active compounds expected to inhibit cancer cell proliferation are piperine, piperidine, stigamsterol, and cysterol. Piperine and piperidine are alkaloid amide compounds which working by activating the apoptosis of cancer thus cell division is controlled (Bezerra et al., 2006; Abrahim et al., 2013).

Table 3. Chemical Compounds of Soursop Leaf Extract

\begin{tabular}{|c|c|}
\hline Location & Compounds \\
\hline Cianjur I & $\begin{array}{l}\text { Hydrofucosterol, } \\
\text { Palmitic acid }\end{array}$ \\
\hline Cianjur II & $\begin{array}{l}\text { Methyl lenoleic, Tetromethyl } \\
\text { hexadecenol, cytosterol }\end{array}$ \\
\hline Cianjur III & $\begin{array}{l}\text { Piperine, Tertomethyl } \\
\text { hexadecenol, Palmitic acid }\end{array}$ \\
\hline Sukat & $\begin{array}{l}\text { Piperine, } \\
\text { Cholesterol }\end{array}$ \\
\hline Sukabumi II & Piperidine, Benzemida, Piperine \\
\hline Sukabumi III & $\begin{array}{l}\text { Gamma cytosterol, Piperin, } \\
\text { Tetromethyl hexadecenol }\end{array}$ \\
\hline
\end{tabular}

\section{Determination of Total Phenolic Compounds}

The total phenolic compounds was calculated base on equations derived from a standard curve prepared from the standard solution. The equation obtained was $\mathrm{y}=$ $0.0069 x+0.0242$ and the regression value was 0.999 . From the calculation, it is found that the highest phenolic compound occur in extract of soursop leaves collected from Sukabumi I (4.94\%) and lowest phenolic compound occur in extract of soursop leaves collected from Cianjur II regions (1.90\%) as shown in Table 4. The difference of total phenol content in soursop leave extracts was due to many environmental factors as altitude, temperature, soil nutrients, harvesting time and plant maintenance methods (Mendez 2001).

Table 4. Total Phenolic Compound of Soursop Leave Extracts

\begin{tabular}{llcc}
\hline \multicolumn{2}{c}{ Location } & Total phenol & Percentage \\
\hline \multirow{4}{*}{ Cianjur } & I & $32.14 \pm 0.807$ & $2.26 \%$ \\
& II & $18.96 \pm 0.753$ & $1.90 \%$ \\
& III & $29.83 \pm 1.150$ & $2.98 \%$ \\
\hline \multirow{3}{*}{ Sukabumi } & I & $49.40 \pm 1.045$ & $4.94 \%$ \\
& II & $21.66 \pm 0.549$ & $2.10 \%$ \\
& III & $22.04 \pm 0.886$ & $2.63 \%$ \\
\hline
\end{tabular}

Cytotoxicity of Soursop Extract On Breast Cancer Cell Line MCF-7 Based On MTT Test

The MTT test was performed to determine the cytotoxicity activity of soursop leaf extract on MCF7 cancer cell line in vitro. The parameter measured in the MTT test is value of $\left(\mathrm{IC}_{50}\right)$. The $\mathrm{IC}_{50}$ or half maximal inhibitory concentration is a measure of the effectiveness of a substance in inhibiting a specific biological or biochemical function, also defined as the concentration or amount of drug needed to kill $50 \%$ the cell population.

Each extract of soursop leaves have shown inhibitory activity on the proliferation of MCF-7 cancer cell. The IC 50 value of the soursop leaves extract collected from Cianjur III occur at concentration of $9.12 \mu \mathrm{gml}^{-1}$ MCF-7. The 
cancer cells were severely damage when the concentration increase to $250 \mu \mathrm{g} \mathrm{ml}^{-1}$. As shown in Figure 1, compared to the soursop leaves extracts collected from other regions, the soursop leaves extract from Cianjur III region have the highest cytotoxic activity to inhibit the growth of MCF-7 cancer cells. The difference of $\mathrm{IC}_{50}$ values are related to variation of biochemical content found in the extracts of soursop leaves, but do not show any correlation with the total phenol content of the extract. Overall, the soursop leaves extracts exhibit the cytotoxic properties to inhibit the proliferation of $\mathrm{MCF}-7$ cancer cells in vitro at concentration higher than the doxorubicin positive control $\left(0.5 \mu \mathrm{g} \mathrm{ml}^{-1}\right)$. The morphological appearance of MCF7 cancer cells when treated with soursop leaves extract at concentration of $250 \mu \mathrm{g} \mathrm{ml}^{-1}$ can be seen in Figure 2. The ability of soursop extracts to diminish the rate of cancer cells proliferation also have been confirmed by many inhibitory capability inhibition. Inhibition of cancer cells from soursop leaves extract previous studies from Moghadamtousi et al. 2014; Moghadamtousi et al.2015. The results suggest that the soursop leaves extract is a potential candidate to be further developed for cancer treatment especially the breast cancer and deserves further research as an alternative to conventional drugs while also stressed out the selection of soursop sample which plays a significant role in determining its potential therapeutic effect on cancer.

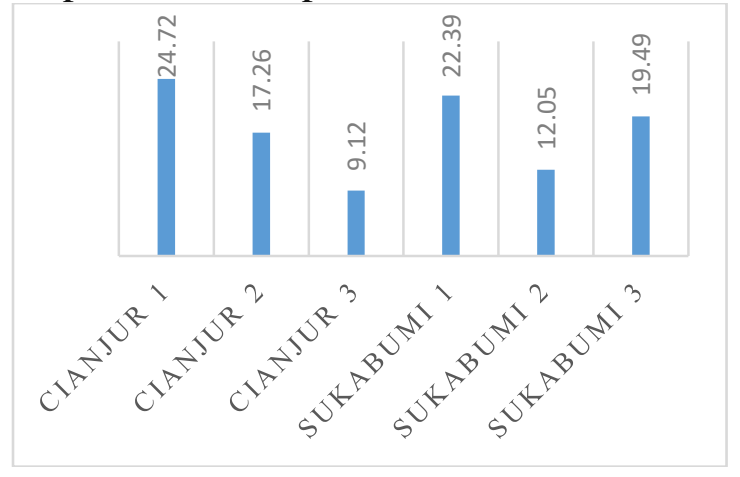

Figure 1. The $\mathrm{IC}_{50}$ Value of Soursop Leaves Extracs Collected From Six Different Regions
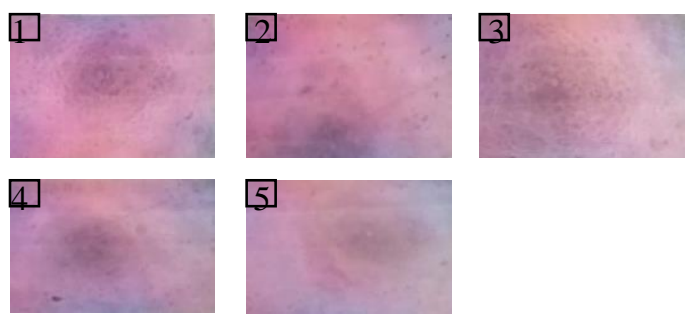

Figure 2. The morphological appearance of MCF7 cancer cells when treated with soursop leaves extract: 1. DMSO 2.

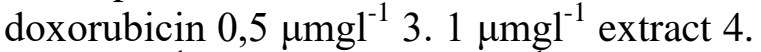
$100 \mu \mathrm{mgl}^{-1}$ extract 5. $250 \mu \mathrm{mgl}^{-1}$. extract

\section{CONCLUSION}

The soursop leaves extracts collected from different regions in west java, Indonesia contain alkaloids, flavonoids, tannins, triterpenoids, and saponins. The MTT test have confirmed that all extracts exhibit the cytotoxic activity against MCF7 cancer cells. The highest activity was shown by is the extract of soursop leaves from collected from Cianjur III with IC $_{50}$ values of $9.12 \mu \mathrm{g} \mathrm{ml}^{-1}$. The Cianjur III soursop leaves extract also contain highest piperine compound with levels reach $8.73 \%$. Finaly, it can be concluded that the geographical region affected the biochemical properties of soursop leaves.

\section{CONFLICT OF INTERESTS}

The authors declare no conflict of interest regarding the publication of this paper.

\section{REFERENCES}

AOAC. 1984. Official Methods of Analysis. Association of Official Analytical Chemist. Washington DC.

Abrahim N.N., M.S. Kanthimathi and A. Abdul-Aziz. 2012. Piper betle shows antioxidant activities, inhibits MCF-7 
cell proliferation and increases activities of catalase and superoxide dismutase. BMC Complement Med. Alternat. 12: 220.

Arifin H., A. Nelvi, H. Dian , R. Roslinda. 2006. Standarisasi ekstrak etanol daun Eugenia cumini. Merr. J. Sains Tek. Far. 11(2): 2006.

Artini N.P.R., S. Wahjuni, and W.D. Sulihingtyas. 2012. Ekstrak daun sirsak (Annona muricata L.) sebagai antioksidan pada penurunan kadar asam urat tikus Wistar. J. Chem. 6 (2): 127-137.

Bezerra D. P., F.O. Castro, A. P. N. N. Alves, C. Pessoa, M. O. Moraes, E.R. Silveira, M. A. Lima, F. J. Elmiro and L. V. Costa-Lotufo. 2006. In vivo growth-inhibition of sarcoma 180 by piplartine and piperine, the alkaloid two amides from Piper Braz. J. Med. Biol. Res. 39(6): 801-806.

Bruton L., J. S. Lazo and K. L. Parker. 2005. Goodman \& Gilman's The Pharmacological Basis of Therapeutics. $11^{\text {th }}$ Edition.McGraw Hill, Lange.

Dai Y, Hogan S, E.M Schmelz, Y.H. Ju, C. Canning, K. Zhou. 2011. Selective growth inhibition of human breast cancer cells by graviola fruit extract in vitro and in vivo involving downregulation of EGFR expression. Nutr Cancer. 63:795-801.

Dong-yun O., Z. Long-hui, P. Hao, X. LiHui, W. Yao, L. Kun-peng, H. Xianhui. Piperine inhibits the proliferation of human prostate cancer cells via induction of cell cycle arrest and autophagy. Food Chem. Toxicol. 60: 424-430.

Florez N., E. Conde and H. Domínguez. 2015. Microwave assited water extraction of plant compunds. $J$. Chem. Technol. Biotechnol. 90 (4): 590-607.
Gajalakshmi S., S. Vijayalakshmi, R. V. Devi. 2012. Phytochemical and pharmacological properties of Annona muricata. Intl. J. Pharm. Pharmaceut. Sci. 4 (2): 3-6.

Harborne J.B. 1987. Phytochemicals Methods: Analyzing the Modern Way Guidance Plant. Translator: Padmawinata K, L Soediro. Penerbit ITB. Bandung.

Hasan A. E. Z. 2013. Production of Indonesia nanopropolis as a antibreastcancer agent. Ph. D Dissertation. Bogor Agricultural University. Bogor.

Hasan A. E. Z., Suryani, S. Estuningsih, F. Fitriannur. 2015. Enterobacter sakazakii be inhibited by Trigona spp propolis from Pandeglang in Indonesia. Intl. J. Pharm. Sci. Bio. 6 (3): 420-428.

Hermawan G. P. and H. Laksono. 2013. Extraction leaves of the soursop (Annona muricata L.) using ethanol. Jurnal Teknologi Kimia dan Industri. 2 (2): 111-115.

IARC. GLOBOCAN 2012. Estimated Cancer Incidence, Mortality and Prevalence Worldwide in 2012. International Agency for Research on Cancer, Lyon.

Kusnandar F., R. A. Dede and F. Mona. 2010. Pendugaan umur simpan produk biskuit dengan metode akselerasi berdasarkan pendekatan kadar air kritis. J. Teknologi Industri Pangan. 21 (2): 117-122.

Lallier B., O. Simeon, Kotochoni, M. Joseph, Hao Zhu. 2014. The characterization of an anxiolytic coumpound from Annona muricata leaf extract: A computational and experimental approach. Master Thesis, Graduate School-Camden, The State University of New Jersey, New Jersey. 
Lin L. and P. L. Hwang. 1991. Antiproliferative effects of oxygenated sterols: Positive corellation with binding affinities for the estrogenbinding sites. Biochem. Biophysica Acta. 1082: 177-184.

Moghadamtousi S.Z. F. Mehran N. Sonia, M. Gokula M. Hapipah and A.B Habsah. 2015. Annona muricata (Annonaceae): A Review of Its Traditional Uses, Isolated Acetogenins and Biological Activities. Int. J. Mol. Sci. (16): 15625-15658.

Moghadamtousi S. Z., H. A. Kadir, M. Paydar, E. Rouhollai and $\mathrm{H}$. Karimian. 2014. Annona

muricata leaves in A549 cells induced apoptosis through mitochondrialmediated pathway and involvement of NF-kB. BMC Alternative Compl. Med. 14(299) 1-13.

Purwatiningsih T., A. Alamudin and S. Noorwati. 2008. Description of medical records of breast cancer disease Dharmais Cancer Hospital in October 1993 until March 2003 Master thesis. Bogor Agricultural University, Bogor.

Rachmani E. P. N., T. S. Suhesti, R. Widiastuti and Aditiyono. 2012. The breast of anticancer from the leaf extract of Annona muricata against cell line in T47D. Intl. J. Appl. Sci. Technol. 2: 157-164.

Raymond W. R. 2007. Cancer Biology. $4^{\text {th }}$ Ed. Oxford University Press. Michigan.

Rodríguez F. J. M., D. M. Pinedo and M. Nodarse. 2010. Assessment of scientific evidence recommending Annona muricata L. (soursop tree) for cancer prevention or treatment. Rev. Cu. Plant Med. 15 (3): 169-181.

Rusmiyati I., Husain and R. G. Diah. 2012. Natural bioactivity of the methanol extract of young leaves of the soursop Annona muricata L. as an antibacterial against Staphylococcus aureus and Propionibacterium acnes. Master Thesis. University of Hasanuddin, Makassar.

Solomon-Wisdom G. O., S. C. Ugoh and B. Muhammad. 2014. Phytochemical screening and antimicrobial activities of Annona muricata (L) leaves extract. Am. J. Biol. Chem. Pharm. Sci. 2 (1): 01-07.

Wamidh H. T. 2011. Anticancer and antimicrobial potential of plantderived natural products. In: Rasooli I, ed. Phytochemicals - bioactivities and Impact on Health. InTech., Croatia, pp. 141-158.

Shah U, Shah R, Acharya S, Acharya N. (2013) Novel anticancer agents from plant sources. Chinese Journal of Natural Medicines. 11: 0016-0023 